\title{
Relationship Between The Education of Parents and Democratic Update Patterns To The Social Development of Early Ages
}

\author{
Rhosma Juarus IIma ${ }^{1}$ \\ ${ }^{1}$ Muhammadiyah Surakarta university,
}

\begin{abstract}
This research aims to see the relationship between parents' educational background and democratic parenting towards children's social development. Methods: the method in this research is quantitative research with a correlational approach. The study population was parents who had early childhood in the village of Sukomoro Magetan Bandar District. Retrieval of population is done using random sampling techniques using large respondents 30 parents. Data collection techniques are using questionnaires or questionnaires. Data analysis technique is multiple linear regression with the help of SPSS. Multiple linear regression techniques include 1 regression equation, 2 partial tests $(\mathrm{t})$, simultaneous tests $(\mathrm{F})$, and the regression coefficient $\mathrm{R} 2$. Results: the results of the data analysis showed that there was a frequency of parental education levels, namely $20 \%$ higher education, $66.6 \%$ high school, $10 \%$ junior high school, and $3.33 \%$ elementary school. There are parents parenting as much as $86.6 \%$ categorized high have implemented democratic parenting while $13.3 \%$ categorized low by applying authoritarian or permissive parenting. While social development as much as $13.3 \%$ was categorized as low and $86.6 \%$ were categorized as high. Conclusion: So it can be concluded that the higher education of older people, then they can have broad knowledge and insight about providing democratic parenting so that it can support the social development of children. $6 \%$ categorized high have implemented democratic parenting while $13.3 \%$ categorized low by applying authoritarian or permissive parenting. While social development as much as $13.3 \%$ was categorized as low and $86.6 \%$ were categorized as high. Conclusion: So it can be concluded that the higher education of older people, then they can have broad knowledge and insight about providing democratic parenting so that it can support the social development of children. $6 \%$ categorized high have implemented democratic parenting while $13.3 \%$ categorized low by applying authoritarian or permissive parenting. While social development as much as $13.3 \%$ was categorized as low and $86.6 \%$ were categorized as high. Conclusion: So it can be concluded that the higher education of older people, then they can have broad knowledge and insight about providing democratic parenting so that it can support the social development of children.
\end{abstract}

\section{KEY WORDS}

educational background, democratic parenting, social development

\section{CORRESPONDING AUTHOR:}

email: rhosmaj@gmail.com

Manuscript submitted October 10, 2020; accepted December 27, 2020.

Copyright: @2020 This is an open access article under the terms of the Creative Commons Attribution License, which permits unrestricted use, distribution, and reproduction in any medium, provided the original author and source are credited.
ECRJ (Early Chilhood Research Journal)

ISSN Numbers: Print, 2655-6448; Online, 2655-9315

\section{ADDRESS}

Website: http://journals.ums.ac.id/index.php/ecrj

Address: Pendidikan Guru PAUD

Universitas Muhammadiyah Surakarta

A. Yani Street No. 1, Pabelan, Kartasura, Surakarta, Indonesia

Telp. +62-271-717417 ext.

Email: ecrj@ums.ac.id 
http://journals.ums.ac.id/index.php/ecrj

\section{INTRODUCTION}

Education is a process of developing potential, ability, and placing students as subjects of education that are controlled by habits, so that it can be improved by good activities, facilitated with props that are arranged as well as possible so as to achieve the stated goals, JohnS. Brubacher 1987 in Helmawati (2015). Education helps develop and direct all the potential that children have in order to achieve their entire life goals.Educational activities can provide help to other individuals to emerge the potential that exists in themselves so that they can overcome the life that will be faced with both in the world and the hereafter.

Education is a matter of developing self-knowledge that can be obtained inside or outside an institution and lasts for an individual's lifetime. Education can be done in the surrounding environment such as family, community and school. An institution has a goal so that students can achieve a development, in gaining knowledge with the realization of national goals. The level of education is a continuous stage that has been set by the institution related to the development of students and the level of difficulty of students.

Early childhood education is a period in which to stimulate development in order to achieve all aspects of optimal development. UU no. 20 of 2003 concerning the National Education System Chapter 1, article 1, item 14 states that "Early Childhood Education is a way of educators targeting children from birth to preschool age which is carried out using the help of knowledge stimulation in developing child growth and development so that it has availability in stepping to further education
Relationship Between The Education...

". Child growth and development can be sustained from an early agebecause it is a golden age (golden age) to build the foundation of growth and development first and foremost for children at the age of 0-6 years.

Growth and development that arises from the child may be influenced by the family environment. Parents have a big role and play a big role in the development of children's education. In carrying out their role parents need to provide encouragement, guidance, facilities and motivation so that adequate education is achieved for the child. Parents' insights and views influence the laying down of parenting given to children. As for education, it is not only formal education but through nonformal education that is very influential in care so that children get what is needed in their development.

The educational background of parents can affect the developmental knowledge given to children. Parent's schooling level is one of the pillars of children's development, the school's level of qualified parents will receive a lot of knowledge, especially regarding how to provide good stimulation. Parents can be said to be the main teacher even though many do not understand the nature of education for their children. Parents' background indirectly gives a big influence in the continuity of children's education. The better the education of parents, the more knowledge they will broaden in stimulating children.

Parents have the full role and responsibility of children's education. Stimulation and habituation given by parents can be emulated by children, so 
http://journals.ums.ac.id/index.php/ecrj

parents must maintain their potential and develop so that children can grow and develop. Planting a good habituation by parents or adults will be easier in the example by children.

According to Hasan Maimunah (2010) the task of parents in providing learning is to stimulate early knowledge, attitudes, and initial skills to comply with policies, and provide good habits for children. In addition, the contribution of the family is to educate the norms and behavior in accordance with what is taught in schools. According to Hurlock in Tridhonanto (2014) the actions given by parents towards children can shape the attitudes and personalities of children. In this case parents need to capture and interpret appropriate parenting to be given to children.

Tridhonanto (2014) states that giving a parenting model is an act of correlation that parents take care of children, while parents provide support in shaping good, correct character and norms so that children can be independent, grow and develop well, have a high sense of trust, want to know, and adapt well. Parenting has an important contribution in shaping the moral and social development of children.

Unfortunately, some parents who provide parenting are less good and ineffective. This will have a bad impact on children. Parenting that restrains and limits the child will cause and hinder child development. Wilis in herlina (2018) causes that lead to parenting is another (1) level of education, (2) basic patterns of guidance applied by parents, (3) parental profession and economic status.

There are 3 forms of parenting, namely: (1) authoritarian parenting that
Relationship Between The Education... implements parents tends to curb, prohibit, and limit the activities implemented by children, (2) democratic parenting is a parenting style with the style of educating the parents in terms of opportunities and concessions to children when exploring the environment, (3) permissive parenting style with parenting style gives leeway without monitoring activities by children. Parents with education in tertiary education will have broad knowledge so as to provide democratic parenting, they realize that good interaction with children will have a good influence without coercion on children.

Democratic parenting is a guiding model that applies children's looseness and gives children to think critically in order to shape character by prioritizing children's needs with logical opinions. Democratic parenting implements respecting parents, whatever the child does, associating children when forming decision, and parents with a view of stimulus to the needs of children. Implementing proper parenting will affect the child's growth and development well.

A child experiences organism changes leading to a phase of maturity or readiness which erupts in a structured, progressive and continuing way up to the physical or psychological Joseph (2011). According to Hurlock, development is the addition and expertise of the body's structure and better use as a result of the maturation of the individual. Early childhood development includes 6 aspects of development, namely the development of religious and moral values, physical motorics, cognitive, language, social emotions, and art. 
http://journals.ums.ac.id/index.php/ecrj

Syamsul in Mursid (2017) states that social development is the result of readiness in social relations to the environment. Social development can be defined how to adapt to the surrounding environment. Children's social behavior initially modeled on the behavior of parents, caregivers, level friends or those around him. According to Siti (2019) psychosocial development can be obtained by children due to interactions with the surrounding environment.

In relationships and interactions do not always run smoothly, some are accepted or rejected. Harlock in Mulyani (2018) factors that influence interaction and socializing, namely (1) the opportunity to socialize, (2) the situation together with people around, (3) children will learn to socialize if they have motivation, (4) learning methods that effective is important.

From the description and temporary research of researchers on educational background and democratic parenting towards the social development of early childhood. Personality, character, and social emotions of a good child will be supported by proper parenting. The educational background of parents can have an impact on the insight of parenting knowledge applied to children. Then the purpose of this research is to find out the relationship between the level of education and parenting parents on social development of young children, the researcher will examine the issue and take the title "Relationship of Parental Education Background and Democratic Parenting Against Social Development of Early Childhood ".
Relationship Between The Education....

This research model is a quantitative study with a correlational approach. According to Sugiono (2018) the design of this research is quantitative research which means that the research method is based on actual ideology, which can be used to study a society or some research objects, information retrieval with research tools, measurement of quantitative / statistical information, is expected to further can be tested according to the hypothesis.

This research was conducted in Bandar Village, Sukomoro Subdistrict, Megetan Regency. The target population is all parents in Bandar Village, Sukomoro Subdistrict, Megetan Regency with side techniques used by using random sampling. The objects in the study were parents and early childhood as many as 30 parents and 30 early children.

Data collection techniques in research is a questionnaire / questionnaire. Questionnaire is a way of grouping data to present a statement for, (Sugiyono, 2018). This observation questionnaire is needed because in order to obtain quantitative data about the educational background of parents and democratic parenting dealing with the social development of children.

In this examination by developing three types of research, namely parents' educational background, parenting, and children's social development. The total statements in the research questionnaire were 38 items. The 38 statement items are presented in the form of a checklist on each statement with five alternative answers. The five answers include: SS (strongly agree), S (agree), RG (doubtful), TS (disagree), STS (strongly disagree). To

\section{Method}


http://journals.ums.ac.id/index.php/ecrj obtain true, complete, and correct data, data analysis is needed.

Data analysis technique is multiple linear regression with the help of SPSS. Multiple linear regression techniques include 1 regression equation, 2 partial tests $(t)$, simultaneous tests $(F)$, and the regression coefficient R2. Furthermore, this research was tested using linear regression test with the formula.

$$
y=\propto+\beta_{1} x_{1}+\beta_{2} x_{2}+e
$$


Table 1.1

Indicator instrument questionnaire

\begin{tabular}{|c|c|c|c|}
\hline Variable & $\begin{array}{r}\text { Sub } \\
\text { Variable }\end{array}$ & Indicator & $\begin{array}{c}\text { Item } \\
\text { Problem }\end{array}$ \\
\hline $\begin{array}{l}\text { Parental } \\
\text { education }\end{array}$ & Parents & $\begin{array}{l}\text { 1. Educational back ground } \\
\text { 2. Understanding parenting }\end{array}$ & $\begin{array}{l}1,2,7 \\
3,4,5,6\end{array}$ \\
\hline \multirow[t]{3}{*}{ Parenting style } & Authoritarian & $\begin{array}{l}\text { 1. Supervision of children is } \\
\text { hard } \\
\text { 2. Children are required to obey } \\
\text { the wishes of parents } \\
\text { 3. Communication is } \\
\text { commanding }\end{array}$ & $\begin{array}{l}1,2 \\
5 \\
3,4\end{array}$ \\
\hline & Democratic & $\begin{array}{l}\text { 1. Supervisors in children are } \\
\text { relatively fiee } \\
\text { 2. Children are also involved in } \\
\text { solving problems and making } \\
\text { decisions } \\
\text { 3. Communication is warm }\end{array}$ & $\begin{array}{l}6.9 \\
7 \\
8,10\end{array}$ \\
\hline & Permissive & $\begin{array}{l}\text { 1. Supervision in children is very } \\
\text { fiee without any direction } \\
\text { 2. connection is very child } \\
\text { dependent } \\
\text { 3. Lack of punishment for } \\
\text { children }\end{array}$ & $\begin{array}{l}11,13 \\
14,15 \\
12\end{array}$ \\
\hline $\begin{array}{l}\text { Early childhood } \\
\text { development }\end{array}$ & $\begin{array}{l}\text { Social } \\
\text { development }\end{array}$ & $\begin{array}{l}\text { 1. Presenting inner courage } \\
\text { adjust to the situation } \\
\text { 2. Do what the child does for the } \\
\text { behavior } \\
\text { goodness of yourself } \\
\text { 3. Adaptations with fiends at } \\
\text { the same level } \\
\text { 4. Want to give to the } \\
\text { environment }\end{array}$ & $\begin{array}{c}3,6,13 \\
7.12 \\
1 \\
4,8,9,11,1 \\
4,15 \\
2,5,19\end{array}$ \\
\hline
\end{tabular}

Table 1.2

Instrument of parental educational background statement

\begin{tabular}{|c|l|l|l|l|l|l|}
\hline \multirow{2}{*}{ No } & \multicolumn{2}{|c|}{ Statement } & \multicolumn{4}{c|}{ The answer } \\
\cline { 5 - 7 } & & SS & S & RG & TS & STS \\
\hline 1 & $\begin{array}{l}\text { My educational background influences the } \\
\text { provision of parenting to children }\end{array}$ & & & & \\
\hline 2 & $\begin{array}{l}\text { I believe that the educational background does } \\
\text { not affect the social development of children }\end{array}$ & & & & & \\
\hline 3 & I understand authoritarian parenting & & & & & \\
\hline 4 & I understand democratic parenting & & & & & \\
\hline 5 & I understand permissive parenting & & & & & \\
\hline 6 & $\begin{array}{l}\text { I understand the child's growth and } \\
\text { development }\end{array}$ & & & & & \\
\hline 7 & $\begin{array}{l}\text { I believe that parenting is not established with } \\
\text { parental education }\end{array}$ & & & & & \\
\hline 8 & $\begin{array}{l}\text { I always provide guidance in order to support } \\
\text { the child's growth and development }\end{array}$ & & & & & \\
\hline
\end{tabular}

Table 1.3

Instrument parenting statement

\begin{tabular}{|c|c|c|c|c|c|c|}
\hline \multirow{2}{*}{ No } & \multirow{2}{*}{ Statement } & \multicolumn{5}{|c|}{ The answer } \\
\hline & & SS & $\mathrm{s}$ & RG & TS & STS \\
\hline 1 & I always set some rules that children must follow & & & & & \\
\hline 2 & I am in control under any circumstances & & & & & \\
\hline 3 & I punish children if they make mistakes & & & & & \\
\hline 4 & $\begin{array}{l}\text { I am very angry if what I command is not } \\
\text { followed by children }\end{array}$ & & & & & \\
\hline 5 & $\begin{array}{l}\text { I often make my own decisions for the good of } \\
\text { the child }\end{array}$ & & & & & \\
\hline 6 & $\begin{array}{l}\text { I release and give direction to the child to make } \\
\text { his choice }\end{array}$ & & & & & \\
\hline 7 & $\begin{array}{l}\text { I tell the kids about the rules of the game before } \\
\text { they do anything }\end{array}$ & & & & & \\
\hline 8 & $\begin{array}{l}\text { I always give my free time to be able to } \\
\text { communicate with children }\end{array}$ & & & & & \\
\hline 9 & $\begin{array}{l}\text { I appreciate and support all the work done by } \\
\text { children }\end{array}$ & & & & & \\
\hline 10 & I listen to whatever the child wants to say & & & & & \\
\hline 11 & I allow children to do whatever they want & & & & & \\
\hline 12 & $\begin{array}{l}\text { I fulfill whatever the child wants without } \\
\text { exception }\end{array}$ & & & & & \\
\hline 13 & $\begin{array}{l}\text { When children make mistakes I still support } \\
\text { without giving direction }\end{array}$ & & & & & \\
\hline 14 & $\begin{array}{l}\text { I do not reprimand or advise a child when making } \\
\text { mistakes }\end{array}$ & & & & & \\
\hline 15 & $\begin{array}{l}\text { I never give praise when a child } \\
\text { committing commendable deeds }\end{array}$ & & & & & \\
\hline
\end{tabular}

Table 1.4

Instrument of social development statements

\begin{tabular}{|c|l|l|l|l|l|l|}
\hline \multirow{2}{*}{ No } & \multicolumn{5}{|c|}{ statement } & \multicolumn{4}{|c|}{ The answer } \\
\hline & & SS & S & RG & TS & STS \\
\hline 1 & $\begin{array}{l}\text { My son wants to try to join playing with his } \\
\text { peers }\end{array}$ & & & & \\
\hline 2 & $\begin{array}{l}\text { My child helps with the toys that have been } \\
\text { used }\end{array}$ & & & & & \\
\hline 3 & $\begin{array}{l}\text { My child is easy to socialize with new } \\
\text { friends }\end{array}$ & & & & & \\
\hline 4 & My child wants to lend a toy to his friend & & & & & \\
\hline 5 & $\begin{array}{l}\text { My child wants to respect the opinions of his } \\
\text { playmates }\end{array}$ & & & & & \\
\hline 6 & $\begin{array}{l}\text { My child wants to calm a friend who is } \\
\text { crying }\end{array}$ & & & & & \\
\hline 7 & $\begin{array}{l}\text { Children show an independent attitude when } \\
\text { doing something }\end{array}$ & & & & & \\
\hline 8 & $\begin{array}{l}\text { My child wants to help friends when they } \\
\text { need help }\end{array}$ & & & & & \\
\hline 9 & $\begin{array}{l}\text { My child is accustomed to helping when he } \\
\text { is in the neighborhood }\end{array}$ & & & & \\
\hline 10 & My child likes to praise the work of others & & & & & \\
\hline
\end{tabular}




\section{RESULTS AND DISCUSSION \\ Results}

In order to find out the results of the study found a relationship between parents' background and democratic parenting towards the social development of children. Researchers analyze the questionnaire instrument before conducting research on respondents. Then the main thing that is done is the validity and reliability tests of the three variables which are as follows:

1. description of research data respondent characteristics

a. age

Table 1.1 age frequency of parents

\begin{tabular}{|r|r|r|}
\hline & Freque & Perce \\
\hline 27 & 2 & 6.666 \\
& & 667 \\
\hline 28 & 1 & 3.333 \\
& & 333 \\
\hline 29 & 3 & 10 \\
\hline 30 & 4 & 13,33 \\
& & 333 \\
\hline 31 & 2 & 6.666 \\
& & 667 \\
\hline 32 & 1 & 3.333 \\
& & 333 \\
\hline 33 & 1 & 3.333 \\
& & 333 \\
\hline 34 & 3 & 10 \\
\hline 35 & 3 & 10 \\
\hline 36 & 1 & 3.333 \\
& & 333 \\
\hline 37 & 4 & 13,33 \\
& & 333 \\
\hline & & \\
\hline
\end{tabular}

\begin{tabular}{|c|c|c|}
\hline 38 & 2 & $\begin{array}{r}6.666 \\
667\end{array}$ \\
\hline 39 & 1 & $\begin{array}{r}3.333 \\
333\end{array}$ \\
\hline 40 & 1 & $\begin{array}{r}3.333 \\
333\end{array}$ \\
\hline 44 & 1 & $\begin{array}{r}3.333 \\
333\end{array}$ \\
\hline tal & 30 & 100 \\
\hline
\end{tabular}

Diagram 1.1 frequency of parental age

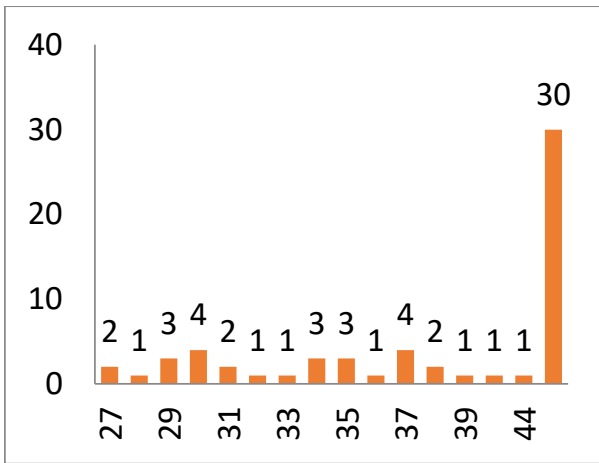

Based on the table and diagram above shows the age of parents who have become research respondents. Age of parents between 27 years and 44 years.

b. Gender

table 1.2 gender frequency

\begin{tabular}{|c|c|c|}
\hline & $\begin{array}{l}\text { Frequen } \\
\text { cy }\end{array}$ & $\begin{array}{l}\text { Percen } \\
\text { t }\end{array}$ \\
\hline L. & 10 & $\begin{array}{r}33,333 \\
33\end{array}$ \\
\hline P. & 20 & $\begin{array}{r}66,666 \\
67\end{array}$ \\
\hline al Tot & 30 & 100 \\
\hline
\end{tabular}




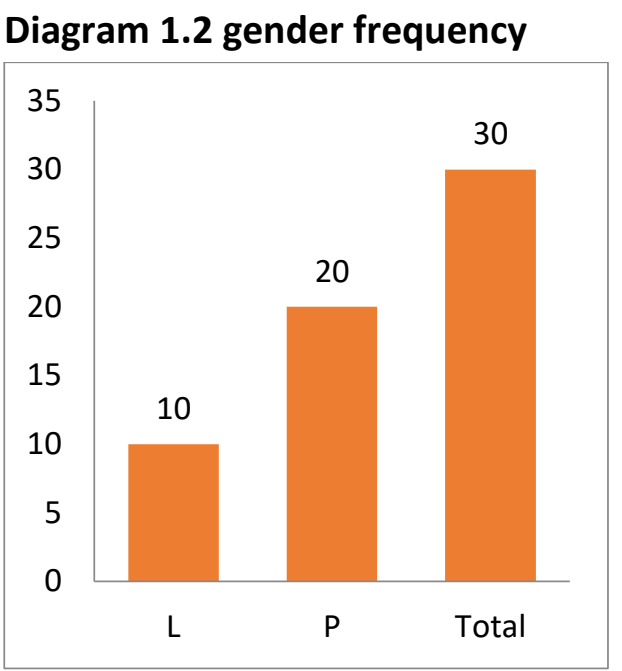

Based on the table and diagram above, the number of respondents is 10 men and 20 women with a percentage of $33.3 \%$ for men and $66.6 \%$ for women.

c. Education

Table 1.3 frequency of education levels

\begin{tabular}{|c|c|c|}
\hline & $\begin{array}{l}\text { Frequ } \\
\text { ency }\end{array}$ & $\begin{array}{l}\text { Perce } \\
\text { nt }\end{array}$ \\
\hline $\begin{array}{r}\text { Elemen } \\
\text { tary school }\end{array}$ & 1 & $\begin{array}{r}3.333 \\
333\end{array}$ \\
\hline $\begin{array}{l}\text { Middle } \\
\text { School }\end{array}$ & 3 & 10 \\
\hline $\begin{array}{l}\text { High } \\
\text { school }\end{array}$ & 20 & $\begin{array}{r}66,66 \\
667\end{array}$ \\
\hline PT & 1 & $\begin{array}{r}3.333 \\
333\end{array}$ \\
\hline Total & 30 & 100 \\
\hline
\end{tabular}

\section{Diagram 1.3 frequency of education} level

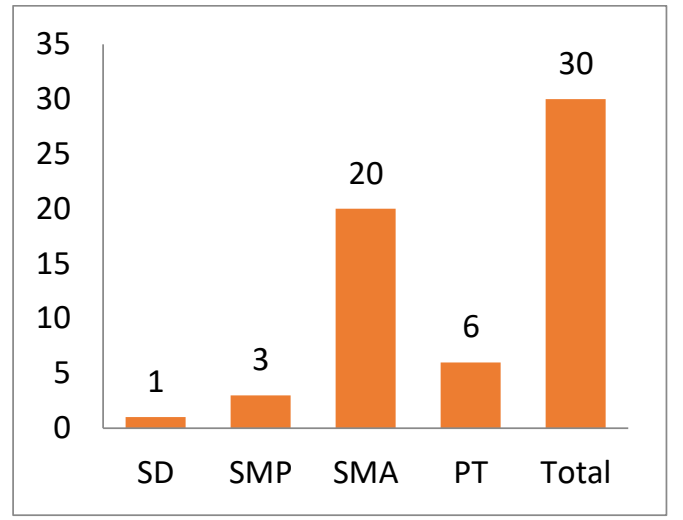

Based on the table and diatan shows the frequency of parental education levels. Frequency of education levels include: $20 \%$ higher education, $66.6 \%$ high school, $10 \%$ middle school, and $3.33 \%$ elementary school.

d. Democratic parenting

table 1.4 frequency of democratic parenting

\begin{tabular}{|c|r|r|}
\hline & \multicolumn{2}{|c|}{$\begin{array}{c}\text { Frequ } \\
\text { ency }\end{array}$} \\
& nt \\
\hline Democ & 26 & 86,66 \\
ratic & & 667 \\
\hline Etc & 4 & 13,33 \\
& & 333 \\
\hline Total & 30 & 100 \\
\hline
\end{tabular}

\section{Diagram 1.4 frequency of democratic parenting}




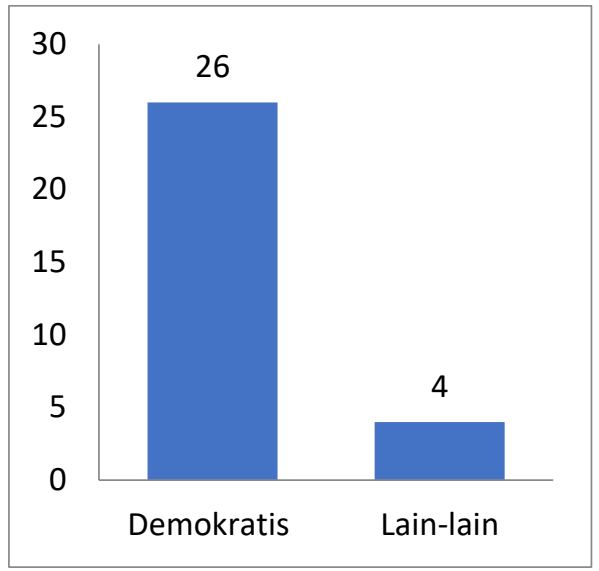

Based on tables and diagrams, there are 4 non-democratic parenting frequency with a presentation of $13.33 \%$ if $<55.5$ and a democratic parenting frequency of 26 with a frequency of $86.66 \%$ if $>55.5$.

e. social development

table 1.5 frequency of social development

\begin{tabular}{|c|c|c|}
\hline & $\begin{array}{l}\text { Frequen } \\
\text { cy }\end{array}$ & Percent \\
\hline$w^{\text {LO }}$ & 4 & $\begin{array}{r}13,333 \\
33\end{array}$ \\
\hline $\begin{array}{ll} & \text { HIG } \\
\mathrm{H} & \end{array}$ & 26 & $\begin{array}{r}86,666 \\
67\end{array}$ \\
\hline $\begin{array}{ll} & \text { Tot } \\
\text { al } & \end{array}$ & 30 & 100 \\
\hline
\end{tabular}

\section{Diagram 1.5 frequency of social development}

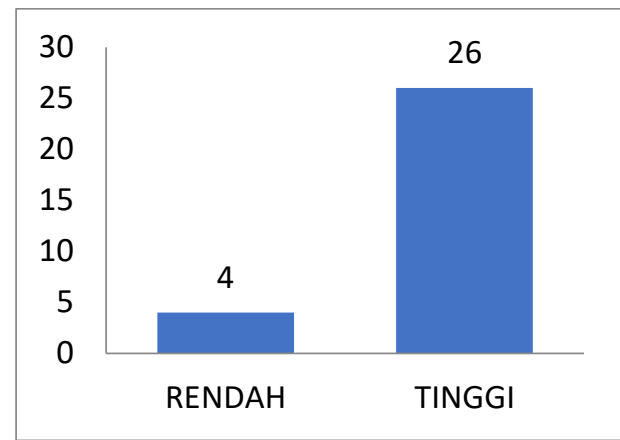

Based on tables and diagrams, there are 4 low frequencies with a presentation of $13.33 \%$ if $<55.5$ and high frequency totaling 26 with a frequency of $86.66 \%$ if $>$ 55.5 .

2. Test the validity of the instrument

The questionnaire in this study there were 38 statement items which were divided into three variables. Each indicator consists of 8 statements regarding the educational background of parents, 15 statements regarding parenting, and 15 statements regarding the child's social development. The questionnaire instance was said to be valid because $r$ count $>r$ table. So to find out the validity of the questionnaire instrument then the validity test is performed. Because the number of samples in the category is small (30) the validity test is carried out with the same amount. Taking a number of samples less than 100 then tested as a whole. Then the cross alpha was found 0.920> 0.05. Reliability results between $0.80-1.00$ means that reliability is very high.

3. Normality test

Based on data that has been tested on 30 respondents. The results of the 
normality of the collected data were then tested using the Shavirowilk test.

Table 1.6 normality test

\begin{tabular}{|r|c|c|}
\hline $\begin{array}{r}\text { variable } \\
\text { I education } \\
\text { background }\end{array}$ & $\begin{array}{c}\text { Sig. } \\
0.5\end{array}$ & $\begin{array}{c}\text { norm } \\
\text { al }\end{array}$ \\
\hline Parenti & 0.5 & \\
ng & 7 & normal \\
\hline $\begin{array}{l}\text { Social } \\
\text { developme } \\
\text { nt }\end{array}$ & 1 & $\begin{array}{l}\text { norm } \\
\text { al }\end{array}$ \\
\hline
\end{tabular}

So that it can be interpreted data obtained from the variable background of parental education and democratic parenting towards social development> 0.05 then the normal distributor.

4. Multicollinity Test

Table 1.7 Collinearity Statistics

\begin{tabular}{|c|c|c|c|}
\hline $\begin{array}{l}\text { Vari } \\
\text { able }\end{array}$ & $\begin{array}{r}\mathrm{t} \\
\text { oler } \\
\text { ance }\end{array}$ & if & ket \\
\hline $\begin{array}{l}\quad \text { Pare } \\
\text { ntal } \\
\text { educatio } \\
\mathrm{n} \\
\text { backgro } \\
\text { und }\end{array}$ & 983 & $\begin{array}{l}\text {,01 } \\
8\end{array}$ & $\begin{array}{l}\text { Ther } \\
\mathrm{e} \text { is no } \\
\text { multicolli } \\
\text { nity }\end{array}$ \\
\hline $\begin{array}{l}\text { Pare } \\
\text { nting }\end{array}$ & 983 & $\begin{array}{l}08 \\
1\end{array}$ & $\begin{array}{l}\text { Ther } \\
\text { e is no } \\
\text { multicolli } \\
\text { nity }\end{array}$ \\
\hline
\end{tabular}

5. Autocorrelation test

After completing the multicolinerity test, the next step is the autocorrelation test. In the autocorrelation test a value of 1.749 is obtained meaning that if the value is between -2 to +2 that can be called a non-autocorrelation value.

6. Regression test

a. Regression equation

In the regression equation test it can utilize the following formula:

$Y=11,627+0,833+0,283+e$

That is, if the value of parents' educational level and parenting is constant (constant or no change, the value of early childhood social development is 11.662). Every addition of 1 point in parental education can increase a child's social development by 0.833 .

b. Test partially (t)

Table 1.8Coefficientsa

\begin{tabular}{|c|c|c|c|}
\hline $\begin{array}{l}\text { Vari } \\
\text { able }\end{array}$ & $\mathrm{T}$ & g. $\quad$ & et $k$ \\
\hline $\begin{array}{l}\quad \text { Pare } \\
\text { ntal } \\
\text { educatio } \\
\mathrm{n} \\
\text { backgro } \\
\text { und }\end{array}$ & $713^{3,}$ & $01^{.0}$ & $\begin{array}{l}\quad H \\
\text { o } \\
\text { refu } \\
\text { sed }\end{array}$ \\
\hline $\begin{array}{l}\text { Pare } \\
\text { nting }\end{array}$ & $181^{2,}$ & $038^{0 .}$ & $\begin{array}{l}\quad H \\
\text { o } \\
\text { refu } \\
\text { sed }\end{array}$ \\
\hline
\end{tabular}

Based on the partial test results indicate the variable Parents 'educational background has a sig value of $0.001<0.05$ h0: rejected 
means that there is a relationship of parents' educational background to the child's social development.The test results partially determine the variableparenting with a sig value of $0.038<0.05$ h0: rejected means that there is a relationship between parenting to the social development of children

c. Simultaneous Test (F)

\section{Table 1.9ANOVAb}

\begin{tabular}{|c|c|c|}
\hline$F$ & Sig. & ket \\
\hline \multirow[t]{3}{*}{8,354} & .001 & Ho \\
\hline & & was \\
\hline & & rejected \\
\hline
\end{tabular}

Based on simultaneous test results that refer to sig values. $0.0001<0.05$ h0: rejected that there is a significant simultaneous relationship between parents' educational background and parenting towards the social development of early childhood.

\section{d. Coefficient $r 2$}

Based on the results of the regression coefficient shows the $r$ square value of 0.336 meaning that $33.6 \%$ of social development variables are influenced by the variables of parental education background and the remaining $66.4 \%$ parenting is influenced by other variables outside the research variable.
Based on observations and studies that have been carried out to 30 populations, 10 parents are categorized as male (father) and 20 female (mother).

In Islamic research (2018) found that a father has an influential role in the child's psychosocial development. A father needs to understand how important it is to build a child's character. Similarly, the role of a mother is also important in supporting the growth and development of children.

From a study of 30 respondents there were vulnerable ages between 27 to 44 years.

The age range of 27 to 44 years is the stage of adulthood. Where as in research Siti (2019) found that someone with an adult age in the psychosocial stage will form the character of a household that can support and educate children as future successors.

According to Jumali et al (2008) the level of education is the level of education that is determined based on the level of development of students, the objectives to be obtained and improved skills. This can be supported by Naolaka (2017) there are 3 types of levels of education, namely basic education, secondary education and higher education.

In a study of 30 respondents found various levels of education, namely 1 person graduated from elementary school, 3 people from junior high school, 20 people from high school, and 6 people graduated from college. Parents with good educational attitudes have practiced democratic parenting so that they can help the child's growth and development. The better the level of parental education can be assumed that parents with extensive

\section{Discussion}


knowledge and insight into early childhood care.

This condition is in accordance with Noor (2020) found that there is an impact from the level of parental education on parenting patterns applied.

According Madyawati (2016) democratic parenting is a parenting that prioritizes the needs of children, but there is still giving direction or controlling children. Parents who apply democratic parenting types are in accordance with the reality that is focused on the child's skills, do not ask for more to increase the limits of children's abilities. Parents also offer breadth to the child to ensure, carry out, and have an opinion on an activity and have a warm approach to the child.

From the results of this study obtained 26 parents who use democratic parenting and 4 parents with authoritarian or permissive parenting. A good level of education for parents can understand and apply democratic parenting

This can be supported by Maccoby \& Mcloby in Madyawati (2016) the causes of the impact of parenting are: (1) education obtained by parents, (2) socioeconomic, (3) religious values, (4) personality. So that the insight of parents can have an impact on providing appropriate parenting for children. Parents with a high level of education can expand knowledge so that children get good parenting.

In this case it can be underlined that there is a relationship between the educational background of parents and democratic parenting.
According to Suyadi (2010) social development is a correlation between children's correlation with the environment around children. Based on the results that have been thoroughly concluded that the social development of children arises by itself because it can be supported by proper parenting. so that it can support the social development of productive children. In addition, permissive and authoritarian parenting practices done by parents have a low percentage, so that children are less well stimulated by parents.

\section{CONCLUSION}

From the results that have been examined, it can be concluded that there is a relevant relationship between the educational background of parents and democratic parenting towards the social development of early childhood in the village of Bandar Magetan. this incident can be seen from the magnitude of $r$ square of $33.6 \%$ can be interpreted the higher level of parental education resulted in parents increasingly understanding good parenting to help social development of young children.

From the research also can be underlined the existence of democratic parenting can be influenced by the age of parents and educational background in order to support the social development of children.

\section{REFERENCES}

Helmawati.2015.Mengenal dan Memahami PAUD.Bandung:PT Remaja Rosdakarya Islamiyati, I., \& Sadiman, S. (2018). Stimulasi Psikososial Keluarga oleh Orang Tua terhadap Perkembangan Anak Usia 4860 Bulan. Jurnal Kesehatan Metro Sai 
Wawai, $\quad$ 11(2), 65. https://doi.org/10.26630/jkm.v11i2.17 74

Jumali, Dkk. 2008. Landasan Pendidikan. Surakarta. Muhammadiyah University Press

JEA (JURNAL EDUKASI AUD) PENDIDIKAN ISLAM ANAK USIA DINI UNIVERSITAS ISLAM NEGERI ANTASARI BANJARMASIN DOI: 10.18592/jea.v6i1.3620. (2020), 6(1), 58-73.

https://doi.org/10.18592/jea.v6i1.362

0

Lestari, S., \& PH, L. (2019). Kemampuan Orangtua dalam Melakukan Stimulasi Perkembangan Psikososial Anak Usia Prasekolah. Jurnal Ilmu Keperawatan Jiwa, 2(3), 123. https://doi.org/10.32584/jikj.v2i3.438 Maimunah, hasan.2010.PAUD (Pendidikan Anak Usia Dini).Yogyakarta:Diva Press Mursid. 2015. Belajar dan Pembelajaran. Bandung: PT Remaja Rosdakarya Neolaka,Amos dan Neolaka,Grace.2017. Landasan Pendidikan Dasar Pengenalan Diri Sendiri Menuju Perubahan Hidup. Depok: Kencana

Sugiyono.2018.metode penelitian.Bandung:Alfabeta

Suyadi.2010.Psikologi belajar PAUD pendidikan anak usia dini.Yogyakarta:Pedagogia

Taufikurrahman, Herlina, \& Sa'd, K. (2018). Jurnal ransformasi Volume 4 Nomor 2 Edisi September 2018 PLS FIP IKIP Mataram. 4(September). http://ojs.ikipmataram.ac.id/index.php/tr ansformasi/article/view/1324 